\title{
ДО ПИТАННЯ ПРО ОСОБЛИВОСТІ СТРУКТУРИ УКРАЇНСЬКИХ ФІРМОНІМІВ
}

Стаття присвячена питанню створення окремого класу власних назв фірмонімів, шо зокрема в структурі ономастичного простору української мови виступають номенами виробничо-комериійних організацій. Специбіка творення онімів цього типу пояснюється екстра- та інтралінгвальними чинниками. Це можна пояснити особливими функиіями фірмонімів: окрім власне номінативної, ідентифікаційної та індивідуалізувально-диферениійної, вони покликані виконувати функиію активізації уваги споживачів і впливу на їхню емочійну сферу; функиію передачі необхідної інформаиї, реалізації оиінного сприйняття об'єкта найменування, а також естетичну, що мають відповідати вимогам комериійного неймінгу, який синтезує маркетингові, лінгвістичні й психологічні критерії до назв об'єктів діяльності людини.

Ключові слова: фірмонім, неймінг, екстра- та інтралінгвальний чинник, комериійна власна назва, структура.

Shcherbakova N. V. About the Problem of Structure of Ukrainian Companies and Enterprises Proper Names. This article deals with the problem of structure of Ukrainian companies and enterprises proper names. The analysis of the proper names of Ukrainian companies and enterprises in Kharkiv showed the prevalence of regional peculiarities in naming as the owners preferred Russian words to name. It is because of the Russian language priority as the language of everyday business communication in Kharkiv. In addition, the choice of foreign language to write the name of the company is often due not so much to the popularity and reputation of the firm as the prestige of the Western mass culture in brand-naming.

As for the structure, company names are divided into one-component names, nouns-appositions, two-component proper names, that are word combinations of different syntactic types. The most part of one-word brand names meet the basic criterion of naming - conciseness, because such personal names of commercial objects are easy to remember, more convenient to use, are not shortened in the documents and therefore are potentially more attractive to the consumers. The lexical filling of the companies names is not always justified when to speak about content of the proper name, its relation to the real motivational base, and the effectiveness of brand names as one of the means of successful business development. Neglect of the Ukrainian standard language norms, which nominators sometimes use, may be successful in creating brand names. As a result of the naming, the companies names can be divided into three groups - informative but obscure; figurative but uninformative; informative 
and imaginative, in which they differently actualize the attractive function. It is the pragmatic aspect in the study of this group of proper names that needs more analysis in perspective.

Key words: proper noun, name of company, name of enterprise, naming, extraand intralinguistic factor, commercial proper name, structure.

\section{Вступ}

Реєстр сучасних назв фірм, організацій та підприємств різного гатунку, що виготовляють продукцію і надають послуги, покликаний зорієнтувати споживача в безмежному обширі необхідної інформації, швидко привернути його увагу й запам'ятатися, оскільки асортимент товарів і послуг, хоча й значний, проте здебільшого однаковий. Отже, створена на ринку конкуренція вимагає від фізичних і юридичних суб’єктів підприємницької діяльності використання всього арсеналу засобів упливу на реципієнта, 3-поміж яких чи не провідну роль відіграє назва самого виробника певного продукту.

Пропріальна лексика на позначення виробничо-комерційних організацій і продуктів їхньої діяльності становила предмет дослідження науковців в аспекті вивчення урбанонімії загалом та ергонімії зокрема. Необхідність виділити фірмоніми (власні назви установ, що виготовляють продукцію і надають послуги) в окремий вектор ономастичних студій, вочевидь, зумовлена динамічними змінами українського ринку товарів і послуг у його внутрішніх і зовнішніх зв'язках. Відповідно, виникла нагальна потреба аналізувати цей корпус власних назв не лише із суто лінгвістичних позицій (лексико-семантичний, словотвірний, функціонально-семантичний), а у плані визначення їхньої маркетингової успішності, передумовою якої має бути вдалий неймінг (від англ. naming - називання, найменування).

«Неймінг - це мистецтво, яке полягає в тому, щоб одним словом схарактеризувати товар чи підприємство, надати їм особливі, привабливі для споживача характеристики та створити позитивне ставлення до них» (Чамерссон, 1999 : 9). Свій унесок у теорію і практику дослідження фірмонімів як результатів якісного / неякісного неймінгу зробили економісти, маркетологи, копірайтери, зокрема А. Френкель, Б. Галі, Г. Чармессон, В. Перція, Е. Слободянюк, М. Блінкіна-Мельник. Однак, уважаємо, передчасно стверджувати, що проблематика вичерпана, через низку причин: 1) сьогодення засвідчує постійні зміни на споживацькому ринку, що неодмінно призводить 
до зникнення / появи одиниць товарообігу й масиву послуг, послаблення / зміцнення конкурентоспроможності певного підприємства / виробника / установи, збільшення /зменшення популярності й затребуваності певних товарів і послуг; 2) асортимент фірмонімів постійно змінюється і кількісно, і якісно; 3) модні тенденції неймінгу спричинюють пошук нових ресурсів мови для ефективного й ефектного називання компаній-виробників та їхньої продукції; 4) творення власних назв цього типу часто відрізняється мовними особливостями регіону. У зв'язку із цим уважаємо за потрібне детально зупинитися на структурних особливостях деяких груп фірмонімів Харкова, що й становитиме мету наукової розвідки.

Матеріалом дослідження послужили назви організацій, що займаються доставкою питної води (15 номенів) і надають послуги 3 оренди автомобілів (7 пропріонімів). Усі мовні одиниці зафіксовані на інтернет-сторінках довідникового видання «Золоті сторінки Харкова» (https://www.goldenpages.ua).

\section{Методи й методики дослідження}

Для досягнення поставленої мети були використані метод суцільної вибірки (для отримання корпусу необхідних власних назв), описовий метод (для кваліфікації особливостей лексичного наповнення пропріонімів), метод структурно-семантичного й частково компонентного аналізу (для виявлення особливостей структури фірмонімів), інтерпретаційний метод (для визначення мотиваційних причин появи онімів), елементи кількісних підрахунків (для унаочнення результатів дослідження).

\section{Результати та дискусії}

В ономастичному просторі мов фірмоніми традиційно відносять до розряду ергонімічної лексики, вивчення якої, на думку Г. Крапівник та Ю. Шпак, відбувалося в декілька етапів: у 60-70-х роках ХХ ст. (інвентаризація й класифікація ономастичного матеріалу; структурний аналіз; формування системи термінів; визначення принципів номінації); у 90-х роках минулого століття (функціональні дослідження ергонімів; принципи й способи номінації, типи мотивованості ергонімних одиниць); від початку XXI ст. й дотепер (студії з виникнення та функціонування власних назв в окремих мовах; зіставні дослідження; вивчення ареальної ергонімії як з позиції семантики та структури, 
так і прагматики; особливості трансформації цих власних назв при перекладі) (Крапівник \& Шпак, 2019 : 77-78).

Комплексна денотатно-номінативна класифікація українського ергонімікону, запропонована М. Торчинським (Торчинський, 2008), засвідчила деталізацію цього корпусу власних назв за декількома рівнями:

1) виділення трьох великих груп - колективоніми («власні найменування колективів, зайнятих у сфері виробництва та сервісу» (Торчинський, 2008 : 273)), конфедераціоніми («власні назви об’єднань людей, держав та інших об'єктів за політичними, ідеологічними та іншими подібними ознаками» (там само)) і пресулатоніми («власні назви керівних структур різних рівнів» (там само));

2) дрібніше групування пропріонімів окресленого типу в межах кожного розряду. Із-поміж колективонімів дослідник пропонує виділяти фабріконіми (власні назви промислових об'єднань), фірмоніми (власні назви колективів фірм), сектуроніми (власні назви колективів шахт, копалень), базоніми (власні назви баз, складів), типографіоніми (власні назви колективів типографій, видавництв), депоніми (власні назви колективів транспортних підприємств), кооперативоніми (власні назви кооперативів, зокрема житлових), фермероніми (власні назви агропідприємств), ветериноніми (власні назви ветеринарних аптек та аналогічних структур), банконіми, бібліотеконіми, готелоніми, курортоніми, медициноніми, монастеріоніми, музейоніми, сервісоніми, спортоніми, фармаціоніми, вокзалоніми, станціоніми, юроніми, міліціоніми, карцероніми, колоніоніми, касоніми, планетаріоніми, поштоніми, комерціоніми, куліноніми, школоніми, академіоніми, людіаріоніми (власні назви колективів театрів, клубів, тобто розважальних закладів), організаціоніми, екіпажоніми, скаутоніми, статівоніми, лепораріоніми (власні назви заповідників та їх колективів), лімітрофони (власні назви прикордонних застав), студіоніми, редакціоніми, агенціоніми, каналоніми, армоніми, ансамблоніми оркестроніми, криміналоніми, командоніми, спортлігоніми, комітетоніми, журіоніми (Торчинський, 2008: 273-285).

Серед конфедераціонімів М. Торчинський виділяє лігоніми (власні назви міждержавних об'єднань), партіоніми, консорціоніми (власні назви спілок і товариств), конфесіоніми й содаліціоніми (власні назви підпільних організацій) (там само). 
Пресулатоніми дослідник розподіляє на міністеріоніми та регнатороніми (власні назви державних та недержавних керівних структур), а також на коетоніми, тобто власні назви нарад і зборів, що мають статус керівного органу (там само).

Ми не ставимо за мету розробити власну класифікацію ергонімів, проте вважаємо за необхідне пояснити свою позицію щодо терміна «фірмонім» як номена для позначення різного типу організацій / установ / виробничих підприємств / фірм, що виробляють продукцію і надають різноманітні послуги.

Уважаємо, що саме цей пропріонім є доцільним у діапазоні наявних термінопозначень названих об’єктів людської діяльності, оскільки має прозору внутрішню форму (онім для позначення фірми), легко сприймається і співвідносний зі звичним для пересічного мовця явищем. Фірмоніми, окрім власне номінативної, ідентифікаційної та індивідуалізувально-диференційної, покликані виконувати функцію активізації уваги споживачів і впливу на їхню емоційну сферу; функцію передачі необхідної інформації, реалізації оцінного сприйняття об’єкта найменування, а також естетичну. Отже, правильно створені фірмоніми, по суті, демонструють результат успішного неймінгу, основними критеріями якого В. Перція називає такі: лаконічність та змістовність назви; відмінність їі від інших та унікальність; пов'язаність із реальністю; здатність мотивувати комунікаційний процес; здатність до запам'ятовування, візуальна й аудіювальна привабливість, позбавленість негативних асоціацій (Перция, 2005). На думку Е. Слободянюк, при створенні неймів (фірмонімів - пояснення наше Н.Щ.) необхідно уникати: використання прізвища засновника, особливо якщо прізвище є дуже поширеним або невиразним; копіювання, «імітації» відомих назв, порожніх абревіатур, що погано запам'ятовуються і можуть бути використані ким завгодно; назв-одноденок, прив'язаних до резонансної події; описових назв, що точно повідомляють специфіку товару, але не викликають емоцій і погано запам'ятовуються (Слободянюк, 2017).

Реєстр проаналізованих фірмонімів - назв компаній Харкова, що надають послуги з доставки питної води та оренди автомобілів, засвідчив:

- різну графіку оформлення власної назви, зокрема наявні одиниці російськомовного написання (10 номенів фірм, що займаються 
постачанням води - «Авита-сервис», «Аква-сервис», «Акваком-плюс», "Аквамир", «Аквасервис», "Лазурная», «Пан водовоз», «Пейвода», «Рощинская», «Слобожанская», «Аква Дива», «Эталон», і 3 надають автомобілі в оренду - «Автокемпер Украина», «Афродита», «Магнолия»); українськомовного написання (лише 2 «водних» фірмоніми - «Чиста вода», «Пан водовоз»); іншомовної графіки (2 «водних» фірмоніми «Alivia», «Crystall House» і 3 «автомобільних» - «Race», «Rental», «Sixt»); із графічними елементами різних мов (1 «автомобільний» фірмонім «Лимузин VIP»). Причиною пріоритетності російськомовних одиниць, на нашу думку, $є$ превалювання російської мови в повсякденній комунікації на Харківщині; іншомовність написання фірмонімів, вочевидь, засвідчує прагнення називачів інтенсифікувати атрактивність оніма;

- різноструктурність фірмонімів. 3-поміж них виділяються однослівні найменування (8 «водних» онімів і 5 «автомобільних»); апозитивні номени (3 «водних» пропріоніми - «Авита-сервис», «Аква-сервис», «Акваком-плюс»); двокомпоненті власні назви, що за структурою є підрядними словосполученнями з різними видами зв'язку (4 «водних» назви - «Аква Дива», «Crystall House», «Пан водовоз», «Чиста вода» та 2 «автомобільних» - «Лимузин VIP», «Автокемпер Украина»). Беззаперечна більшість однослівних фірмонімів відповідає базовому критерію неймінгу - лаконічності. Адже короткі власні назви об'єктів комерційно-виробничої діяльності людини швидше запам'ятовуються, є зручнішими у використанні, не скорочуються в документообігу, а отже потенційно більш привабливі для споживача;

- різне лексичне наповнення фірмонімів, що не завжди виправдане в аспекті змістовності власної назви, ії зв’язку з реальною мотиваційною базою, а отже - й ефективності пропріоніма як одного із засобів успішного розвитку бізнесу. Оніми із компонентами «аква» i «вода / вод-» («Аква Дива», «Аква-сервис», «Акваком-плюс», «Аквамир», «Аквасервис», «Пан водовоз», «Пейвода», «Чиста вода») прямо орієнтують на компанії, чия діяльність у певний спосіб пов’язана з водою (позначають воду як продукт або називають маніпуляції 3 нею - возити воду, надавати воду); власні назви «Лазурная», «Рощцнская», «Слобожанская» радше за аналогією до відомих українських брендів «Миргородська», «Моршинська» асоціюватимуться 
у споживачів із водою як продуктом, проте не встановлюватимуть логічного зв'язку з іï постачанням. Пропріоніми «Alivia», «Crystall House», «Эталон», жодним чином не коментуючи вибір назви компанії на власних офіційних сайтах, звичайно, привертають увагу споживача, але спричинюють виникнення широкого кола асоціацій, наприклад, назву «Alivia» могла 6 мати компанія, що постачає оливки, маслини, оливкову олію; “Crystall House» Інтернет пропонує ідентифікувати як новий житловий квартал у Києві (https://jk-crystalhouse. com.ua/), а на запит «Эталон» можемо отримати покликання на харківське бюро перекладів «Эталон» (https://etalon-agency.com), харківський завод залізобетонних конструкцій «Эталон» (https:/ zgbk-etalon.kh.ua) або корпорацію «Эталон» у Борисполі (http://www. baz.ua).

Фірмоніми Харкова на позначення компаній, що надають послуги 3 оренди автомобілів, засвідчують подібну тенденцію. «Зчитування» інформації з власної назви автомобільної фірми вимагає від споживача: 1) знання англійської мови, оскільки розуміння виду діяльності комерційної організації залежить від уміння перекласти назви «Race» ('перегони, гонка, гнати'), «Rental» ('оренда'), а також лексему camper ('будиночок на колесах’), що в транслітерованому вигляді стала компонентом фірмоніма «Автокемпер Украина» - компанії, предметом орендування / продажу якої $є$ не лише автомобілі, а й причіпи - кемпери, призначені для комфортного відпочинку під час автоподорожі; 2) знання фактів з історії орендування автомобілів, адже не кожен одразу зрозуміє напрям діяльності компанії «Sixt» (засновник компанії - Мартін Сікст (Martin Sixt); фірма виникла в Німеччині в 1912 р. і відтоді надає послуги з оренди автомобілів. Це сімейний бізнес, що 2007 р. був названий найкращою орендною компанією Європи. Має свої філії майже по всьому світу). Проте найбільш проблемними з-поміж виділених «автомобільних» фірмонімів є «Афродита» й «Магнолия», які, окрім лаконічності, позитивної конотації та естетичності, не відповідають основному критерію успішного неймінгу змістовності й зв'язку з реальними об'єктами найменування. Вони дезорієнтують споживача, оскільки радше мотивують асоціювання із жіночою красою, любов'ю до жінки і могли бути більш влучними, якби називали перукарню, салон краси або квітковий магазин тощо. Іще одна власна назва компанії - «Лимузин VIP», на нашу думку, є не 
зовсім правильною з позиції мовної норми: перший компонент - лімузин - назва машин представницького класу, другий компонент англійська абревіатура VIP, що розшифровується як very important person - 'дуже важлива персона'. Така назва, по суті, $є$ плеоназмом, оскільки лімузини - це самі по собі машини для дуже важливих персон, хоча зауважимо, що в аспекті вимог комерційного неймінгу цей фірмонім є вдалим.

Слідом за Ю. Бернадською вважаємо, що наведені приклади свідчать про досить типову ситуацію з результатами неймінгу. Утворені фірмоніми можна поділити на три групи - інформативні, але необразні («Аква-сервис», «Автокемпер Украина»); образні, але неінформативні («Афродита», «Магнолия», «Эталон»); інформативні й образні («Пан водовоз», «Пейвода») (Бернадская, 2003: 38).

\section{Висновки}

Аналіз власних назв об’єктів комерційно-виробничої діяльності м. Харкова (уважаємо за правомірне позначати терміном «фірмоніми») продемонстрував превалювання регіональних особливостей неймінгу - власники надавали перевагу російськомовним назвам, оскільки пріоритетною мовою повсякденного ділового спілкування Харківського регіону є російська мова. Окрім того, вибір іншомовного написання оніма часто зумовлений не стільки популярністю й відомістю фірмоніма у світі («Sixt»), скільки престижністю західної масової культури.

За структурою фірмоніми поділяються на однослівні найменування, апозитивні номени, двокомпоненті власні назви, що за структурою є підрядними словосполученнями з різними видами зв'язку. Більша кількість однослівних фірмонімів відповідає базовому критерію неймінгу - лаконічності, оскільки короткі власні назви об'єктів комерційно-виробничої діяльності людини швидше запам'ятовуються, $€$ зручнішими у використанні, не скорочуються в документообігу, а отже, потенційно більш привабливі для споживача. Лексичне наповнення фірмонімів не завжди виправдане в аспекті змістовності власної назви, іiі зв'язку з реальною мотиваційною базою, а тому й ефективності пропріоніма як одного із засобів успішного розвитку бізнесу. Порушення норм української літературної мови, до якого інколи вдаються неймери, в аспекті комерційного найменування можуть бути виправданими. 
Як результат неймінгу, утворені фірмоніми можна поділити на три групи - інформативні, але необразні; образні, але неінформативні; інформативні й образні, у зв'язку із чим вони по-різному актуалізують атрактивну функцію. Саме прагматичні акценти у вивченні цього класу власних назв потребують детальнішого аналізу в перспективі.

\section{ЛІТЕРАТУРА}

1. Бачинська Г. Фонетичні та лексико-семантичні особливості прагмонімів: на матеріалі кондитерських виробів. Наукові записки Тернопільського національного педагогічного університету ім. Володимира Гнатюка. Сер. Мовознавство. 2017. Вип. 1(27). С. 22-26. 2. Бернадская Ю. С. Копирайтинг. Омск: Изд-во ОмГТУ, 2003. 136 с. 3. Блинкина-Мельник М. М. Рекламный текст: Задачник для копирайтеров. Москва: ОГИ, 2007. 200 с. 4. Гали Б. Brand. Рождение имени. Энциклопедия. Пер. с англ Е. Макарова. Москва: Етерна, Палімпсест, 2007. 432 с. 5. Крапівник Г. О., Шпак Ю.О. Сучасний ергонімікон кав'ярень міста Харкова. Лінгвістичні дослідження. Харків: ХНПУ імені Г. С. Сковороди, 2019. Вип. 50. С. 76-85. https://doi.org/10.34142/23127546.2019. 50.10. 6. Перция В. Анатомия бренда. Москва: Эксмо, 2005. 243 с. 7. Слободянюк Э. Клад для копирайтера. Технология создания захватывающих текстов. Харків: Фоліо, 2017. 224 с. 8. Торчинський М. М. Структура онімного простору української мови: моногр. Хмельницький: Авіст, 2008. 548 с. 9. Френкель А. Нейминг. Как игра в слова становится бизнесом: О брендах, торговых марках. Пер. с англ. А. Калинина, Т. Швец. М.: Добрая книга, 2006.360 с. 10. Чаплінський Ю. Б., Іліка Г.П. Неймінг: суть, основні складові та правила створення успішного неймінга підприємства. URL: http://www. rusnauka.com/26_NTP_2014/Economics/6_165588.doc.htm. 11. Чармэссон Г. Торговая марка: как создать имя, которое принесет миллионы. Пер. с англ. Л. Корпан. СанктПетербург: Питер, 1999. 224 с.

\section{REFERENCES}

1. Bachynska, H., Tyshkovets, M. (2017). Fonetychni ta leksyko-semantychni osoblyvosti prahmonimiv : na materiali kondyterskykh vyrobiv [Phonetic and lexicalsemantic peculiarities of pragmonyms: on the material of confectionery]. Naukovi zapysky Ternopilskoho natsionalnoho pedahohichnoho universytetu im. Volodymyra Hnatiuka. Ser. Movoznavstvo - Scientific notes of the Ternopil National Pedagogical University named after Volodymyr Hnatyuk. Series Linguistics, 27, 22-26. [in Ukrainian]. 2. Bernadskaya, Yu. S. (2003). Kopirajting [Copywriting]. Omsk: OmGTU. [in Russian]. 3. BlinkinaMelnik, M. M. (2007). Reklamnyj tekst: Zadachnik dlya kopirajterov [Promotional Text: A copybook for copywriters]. Moskow: OGI [in Russian]. 4. Gali, B. (2007). Brand: Rozhdenie imeni. Enciklopediya [The birth of a name. Encyclopedia]. Moskow: Eterna, Palimpsest [in Russian]. 5. Krapivnyk, H. O. \& Shpak, Yu.O. (2019). Suchasny erhonimikon kaviaren Kharkova [Contemporary Ergonyms for Coffee Houses in Kharkiv]. Linhvistychni doslidzhennia - Linquistic Studies, 50, 76-85. Kharkiv: KhNPU imeni H. S. Skovorody [in Ukrainian]. 6. Perciya, V. (2005). Anatomiya brenda [Anatomy of brand]. Moskow: E'ksmo. [in Russian]. 7. Slobodyanyuk, E'. (2017). Klad dlya kopirajtera. Texnologiya sozdaniya zaxvatyvayushhix 
tekstov [Treasure for the copywriter. Technology to create exciting texts]. Kharkiv: Folio [in Russian]. 8. Torchynskyi, M. M. (2008). Struktura onimnoho prostoru ukrainskoi movy: monohrafiia [Structure of Ukrainian Proper Names Field: Monograph]. Khmelnytskyi: Avist [in Ukrainian]. 9. Frenkel, A. (2006). Nejming. Kak igra v slova stanovitsya biznesom: O brendax, torgovyx markax [Naming: how the game of words becomes a business]. Moskow: Dobraya kniga [in Russian]. 10. Chaplynskyi, Yu. B. \& Ilika, H. P. Neyminh: sut, osnovni skladovi ta pravyla stvorennia uspishnoho neiminhu pidpryiemstva [Naming: the essence, the main components and rules for the creation of a successful company's naming]. Retrived from http://www.rusnauka.com/26_NTP_2014/Economics/6_165588.doc.htm [in Ukrainian]. 11. Charmesson, G. (1999). Torgovaya marka: kak sozdat' imya, kotoroe prineset milliony [The Name's the thing: creating the perfect name for your company or product]. (L. Korpan, Trans.), Sankt-Peterburg: Piter [in Russian].

Щербакова Наталя Володимирівна - кандидат філологічних наук, доцент, доцент кафедри української мови, Харківський національний педагогічний університет імені Г. С. Сковороди. Вул. Валентинівська, 2, Харків, 61168, Україна.

Tel. +38-066-711-12-81

E-mail: shcherbakovanv72@gmail.com

https://orcid.org/0000-0002-5297-9383

Shcherbakova Natalia Volodymyrivna - PhD in Philology, Associate Professor, Ukrainian Language Department, H.S. Skovoroda Kharkiv National Pedagogical University. Valentynivska Str., 2, Kharkiv, 61168, Ukraine.

Надійшла до редакції 25 жовтня 2019 року 